\title{
Morphology of the intestinal mucosa and growth performance of chickens fed diets containing sugar cane extract
}

\author{
O. Khambualai ${ }^{1}$, K. Yamauchi, K. Koge ${ }^{2}$ and J. Kashimura ${ }^{2}$ \\ ${ }^{1}$ Laboratory of Animal Science, Faculty of Agriculture, \\ Miki-cho, Kagawa University, Kagawa-ken, 761-0795 Japan \\ ${ }^{2}$ Mitsui Sugar Co., Ltd., 253-0042 Kanagawa, Japan
}

(Received 17 June 2008; revised version 1 December 2008; accepted 20 March 2009)

\begin{abstract}
To investigate the growth performance and small intestinal histological changes in chickens fed sugar cane extract (SCE), 42 layer-type chicks were divided into three groups of $0,0.05$, and $0.10 \%$ dietary SCE diets. The growth performance tended to be better in all dietary SCE groups. Intestinal villus height, villus area, cell area and cell mitosis number of the duodenum showed a higher values in all the SCE groups, and the cell area of $0.10 \%$ SCE group and cell mitosis of all the SCE groups were higher than the $0 \%$ SCE group $(\mathrm{P}<0.05)$. After feeding of dietary SCE, protuberated cells and aggregation of protuberated cells were found in the duodenum and jejunum, as well as segmented filamentous bacteria appeared in the ileum. These suggest that the dietary SCE might be induce the structural hypertrophy of intestinal villi and epithelial cells on villus tip surface, resulting in the 5$6 \%$ heavier body weight gain in the SCE groups than the control.
\end{abstract}

KEY WORDS: chicken, intestinal, morphology, sugar cane extract

\section{INTRODUCTION}

The latest subject of concern in the agricultural industry is to produce reliable and secure food without using chemical medicines, because the continued use of chemical medicine, antibiotics, and hormones to control many infectious diseases

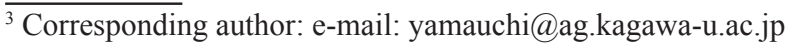


has induced new drug-resistant bacteria (Sorum and Sunde, 2001) and drug residues in the animal body (Burgat, 1991). Some antimicrobial growth promoters were prohibited by the European Union in 2006 (Bywater, 2005). Consequently, the most suitable alternatives are being researched and developed in order to enhance the latent ability of intestinal function through the use of natural substances.

Sugar cane extract (SCE) is the residue after glucose, fructose and sucrose are removed from sugar cane juice, and displays a wide range of biological affects. SCE has an immuno-stimulating effect (El-Abasy et al., 2002), it induces immunosuppression from X-ray radiation (Amer et al., 2004) in normal chickens, improves the immune systems of chickens treated with cyclophophamide (El-Abasy et al., 2004), and enhances immune responses against E. tenella infection in chickens (El-Abasy et al., 2003). Pigs treated with SCE for 3 consecutive days showed a significant enhancement an immuno-stimulative that may provide protection against porcine reproductive respiratory syndrome (Lo et al., 2005). In mice, SCE has a protective effect on endotoxic shock (Motobu et al., 2006). Additionally, SCE has been discussed as having growth-promoting effects in chickens (El-Abasy et al., 2002). In our previous paper using adult layer chickens, SCE activated the adsorptive functions of the small intestinal, resulting in higher values of growth performance in these adult chickens (Yamauchi et al., 2006).

Epithelial cells originated by mitosis in the crypts migrate steadily toward the tips of the villi, where they extrude into the lumen (Imondi and Bird, 1966). It is suggested that scanning electron microscopy allows better understanding of the physiology of the intestinal mucosa and gives three-dimensional images allowing detailed analysis of the structure of epithelial cells, and that the size and activity of extrusion zone is a good marker of epithelial cell turnover (Skrzypek et al., 2005).

Therefore, the purpose of the present study was to examine whether the growth performance of young chicks is affected by feeding SCE from 7 days of age, and to observe the morphological changes of the intestinal villi using light microscopy and epithelial cells on the villus apical surface using scanning electron microscopy in each intestinal part in these birds.

\section{MATERIAL AND METHODS}

\section{Sugar cane extract}

Sugar cane extrac (SCE) was produced from sugar cane juice, and adsorbed into rice-bran oil cakes after the removal of the glucose, fructose and sucrose (Yamauchi et al., 2006). 


\section{Animals}

Forty-two one-day-old layer- or egg-type male Sanuki Cochin chicks were obtained from a livestock experiment station in Kagawa Prefecture (Japan). The birds were reared in brooder battery pens under continuous light and fed a commercial starter layer diet (Table 1; Nippon Formula Feed MFG. Co., Ltd.,

Table 1. Feed formulation and nutrient composition of commercial layer starter and grower mash diet, $\%$

\begin{tabular}{lcc}
\hline Item & $\begin{array}{c}\text { Starter } \\
\text { days } 1 \text { to } 28\end{array}$ & $\begin{array}{c}\text { Grower } \\
\text { days } 28 \text { to } 70\end{array}$ \\
\hline $\begin{array}{l}\text { Ingredients } \\
\text { ground maize }\end{array}$ & 54 & 58 \\
bran & 5 & 14 \\
plant seedcake & 32 & 21 \\
fish meal & 4 & 4 \\
vitamin/ mineral premix ${ }^{1}$ & 5 & 3 \\
Chemical component & & \\
crude protein & 21 & 18 \\
metabolizable energy, MJ/ kg & 12.14 & 11.93 \\
crude fibre & 6.0 & 6.0 \\
crude fat & 2.5 & 3.0 \\
crude ash & 8.0 & 9.0 \\
Ca & 0.8 & 0.7 \\
P, available & 0.55 & 0.5 \\
\hline
\end{tabular}

${ }^{1}$ concentrate mixture including:vitamins: $\mathrm{A}, \mathrm{D}_{3}, \mathrm{E}, \mathrm{K}_{3}, \mathrm{~B}_{1}, \mathrm{~B}_{2}, \mathrm{~B}_{3}, \mathrm{~B}_{12}$, biotin, pantothenic acid, folic acid, nicotinic acid, choline; minerals: zinc, copper

Kanagawa, Japan) until 7 day of age. At 7 day of age, the birds showing an average body weight were assigned randomly and allotted into 3 groups with 4 replicates of 14 birds per replicate. The chickens were placed into individual cages $\left(0.14 \mathrm{~m}^{3}\right.$ space per chick) at room temperature. A commercial diet for layer chickens was used as the basal diet. The starter (CP 21\%, ME $12.14 \mathrm{MJ} / \mathrm{kg}$ ) and grower (CP $18 \%$, ME $11.93 \mathrm{MJ} / \mathrm{kg}$ ) layer diets were used at 0-4 and 4-10 weeks, respectively. SCE was supplemented to a basal diet at $0,0.05$ and $0.10 \%$ levels. During the experiment period, the diet and water were supplied ad libitum. Body weight and feed intake were measured and feed efficiency was calculated every week.

The chickens were handled in accordance with the rules of animal experimentation in the laboratory of animal science, Kagawa University, Kagawa Prefecture (Japan). 


\section{Tissue sampling}

At the end of the feeding period, 4 chickens from each group were weighed and killed by decapitation. The whole small intestine was quickly excised and placed in a mixture of $3 \%$ glutaraldehyde and $4 \%$ paraformaldehyde fixative solution in $0.1 \mathrm{M}$ cacodylate buffer ( $\mathrm{pH}$ 7.4) to fix them. The same fixative solution was also injected into the lumen. The segment from the gizzard to the pancreatic and bile ducts was recognized as the duodenum, the jejunum was measured from the ducts to Meckel's diverticulum, and the ileum was measured from the diverticulum to ileo-caecal-colonic junction. The tissue samples were taken from the middle part of each intestinal segment.

\section{Light microscopy}

For light microscopic observation, $2 \mathrm{~cm}$ of each intestinal segment was transversally cut, fixed in Bouin's fixative solution, and embedded in paraffin wax. Transverse sections $(4 \mu \mathrm{m})$ were cut and every tenth section was collected and stained with haematoxylin-eosin. The following values were measured using an image analyzer (Nikon, Tokyo, Japan). All light microscopic parameters were measured in each intestinal segment.

\section{Measurement of villus height}

The highest villi having the lamina propria were selected for the villus height measurement. Two villus heights per section were measured from the villus tip to the end of the base excepting the crypt. A total of 16 villi were expressed from difference sections in each bird. Finally, the mean villus heights from 4 birds were expressed as a mean villus height for one treatment group.

The apparent villus area was calculated from the villus height, basal width and apical width (Iji et al., 2001). A total of 16 villi were expressed from difference sections in each bird. Finally, the mean villus areas from 4 birds were expressed as a mean villus area for one treatment group.

\section{Measurement of absorptive epithelial cell area}

For the single cell area, the epithelial cell layer was randomly measured at the middle part of the villi. The number of cell nuclei within this was counted. The epithelial cell layer area was divided by the number of cell nuclei to obtain the epithelial cell area. Two cell areas per section were calculated. A total of 8 sections were counted per bird. Finally, the mean cell areas from 4 birds were expressed as a mean cell area for one treatment group. 
Measurement of cell mitoses in the crypt

Mitotic cells having homogenous, intensely stained basophilic nuclei with haematoxylin in one transverse section were counted (Tarachai and Yamauchi, 2000). An average of the 4 different sections was expressed as the mean for each chicken. Finally, the 4 means from 4 birds were expressed as the mean villus for one treatment group.

\section{Scanning electron microscopy}

A 2-cm section from each segment was slit longitudinally along the entire length, opened and washed with $0.1 \mathrm{M}$ phosphate buffered saline ( $\mathrm{pH}$ 7.4). Tissue samples were pinned to the paraffin-covered floor in the petri dish containing the mixture of 3\% glutaraldehyde and $4 \%$ paraformaldehyde fixative solution in 0.1 $\mathrm{M}$ cacodylate buffer ( $\mathrm{pH}$ 7.4) solution to prevent the outward curling of the slit intestinal section. The samples were fixed in this flattened position for $1 \mathrm{~h}$ at room temperature. A block was cut into $4 \times 4-\mathrm{mm}^{2}$ squares, further fixed for $1 \mathrm{~h}$, and postfixed with $1 \%$ osmium tetroxide in a $0.1 \mathrm{M}$ ice-cold sodium cacodylate buffer for $2 \mathrm{~h}$. The pieces were dehydrated in graded ethanol solution and dried in a criticalpoint drying apparatus (Hitachi HCP-1, Hitachi Ltd., Tokyo, 100-8220 Japan) using $t$-butyl alcohol as the medium. The dried specimens were coated with platinum (RMC-Eiko RE vacuum coater, Eiko Engineering Co., Ltd., Tokyo, Japan) at 100 $\mathrm{m}$ Torr under $7 \mathrm{~mA}$ and examined with a scanning electron microscope (Hitachi S$4300 \mathrm{SE} / \mathrm{N}$, Hitachi Ltd., Tokyo, Japan) at $8 \mathrm{kV}$. The morphological changes of the epithelial cells on the villus tip surface were observed.

\section{Statistical analysis}

All data were analysed following the General Linear Model procedure of the Statistical Analysis System (SAS, 1997), and comparison of means were made using Duncan's new multiple range test. The difference among means was considered significant at $\mathrm{P}<0.05$ (Steel and Torrie, 1980).

\section{RESULTS}

Although growth performance was not significantly different amongst the groups, feed intake tended to increase in the groups in correlation with increasing levels of SCE (Table 2). Body weight gain also tended to increase in 
the SCE groups, and the $0.05 \%$ SCE group showed a higher value than the $0.10 \%$ SCE group, resulting in the highest value of feed efficiency in the $0.05 \%$ SCE.

Table 2. Feed intake, body weight gain and feed efficiency of chickens fed the control diet and the dietary 0.05 and $0.10 \%$ SCE diets

\begin{tabular}{lccc}
\hline \multirow{2}{*}{ Item } & \multirow{2}{*}{ Control } & \multicolumn{2}{c}{ Sugar cane extract } \\
\cline { 2 - 4 } & & $0.05 \%$ & $0.10 \%$ \\
\hline Feed intake, g & $3571.4 \pm 42.7$ & $3598.9 \pm 139.3$ & $3799.8 \pm 29.3$ \\
Body weight gain, g & $1239.8 \pm 25.8$ & $1317.7 \pm 6.9$ & $1310.5 \pm 35.9$ \\
Feed efficiency & $0.347 \pm 0.006$ & $0.368 \pm 0.014$ & $0.345 \pm 0.008$ \\
\hline
\end{tabular}

there are no significant different between the control and the experimental treatment $(\mathrm{P}>0.05)$ for any of the variables

Compared with the control, the villus height and villus area of the duodenum showed a tendency to be higher in all experimental groups, except in the case of the jejunal villus area of the dietary $0.05 \%$ SCE group (Figure 1.). The cell area was significantly increased in the duodenum of the $0.10 \%$ SCE group $(\mathrm{P}<0.05)$. Cell mitosis also showed a higher value in all the intestinal segments, except in the ileum of the dietary $0.10 \%$ SCE group, and the duodenal cell mitosis was higher in the SCE groups $(\mathrm{P}<0.05)$.

The control duodenal epithelial cells on the villus tip (Figure $2 \mathrm{~A}$ ) were faintly protuberated (arrows). Feeding dietary 0.05 (Figure 2 B) and $0.10 \%$ SCE (Figure $2 \mathrm{C})$ resulted in a clearer cell protuberance (large arrows) appearing around the central sulcus (arrowheads) in all groups. Furthermore, these cells developed to cell clusters (stars) aggregated by epithelial cells in the $0.05 \%$ SCE group. A few cells having no microvilli (arrow with $\mathrm{C}$ ) were also found.

The jejunal epithelial cells on the villus tip surface of the control group (Figure $3 \mathrm{~A}$ ) were flat (arrows). In the $0.05 \%$ SCE group (Figure 3B), such cells developed to faintly protuberated cells (large arrows). In the $0.10 \%$ SCE group (Figure $3 \mathrm{C}$ ), epithelial cells showed a further protuberated cell (arrows), and some cells devoid of any microvilli (arrow with C) were apparent.

The epithelial cells of the ileal showed similar morphology to the control (Figure 4 A). However, segmented filamentous bacteria (SFB) were observed in SCE groups, which were much greater in quantity in the $0.05 \%$ SCE group (Figure $4 \mathrm{~B}$ ) than in the $0.10 \% \mathrm{SCE}$ group (Figure $4 \mathrm{C}$ ). 

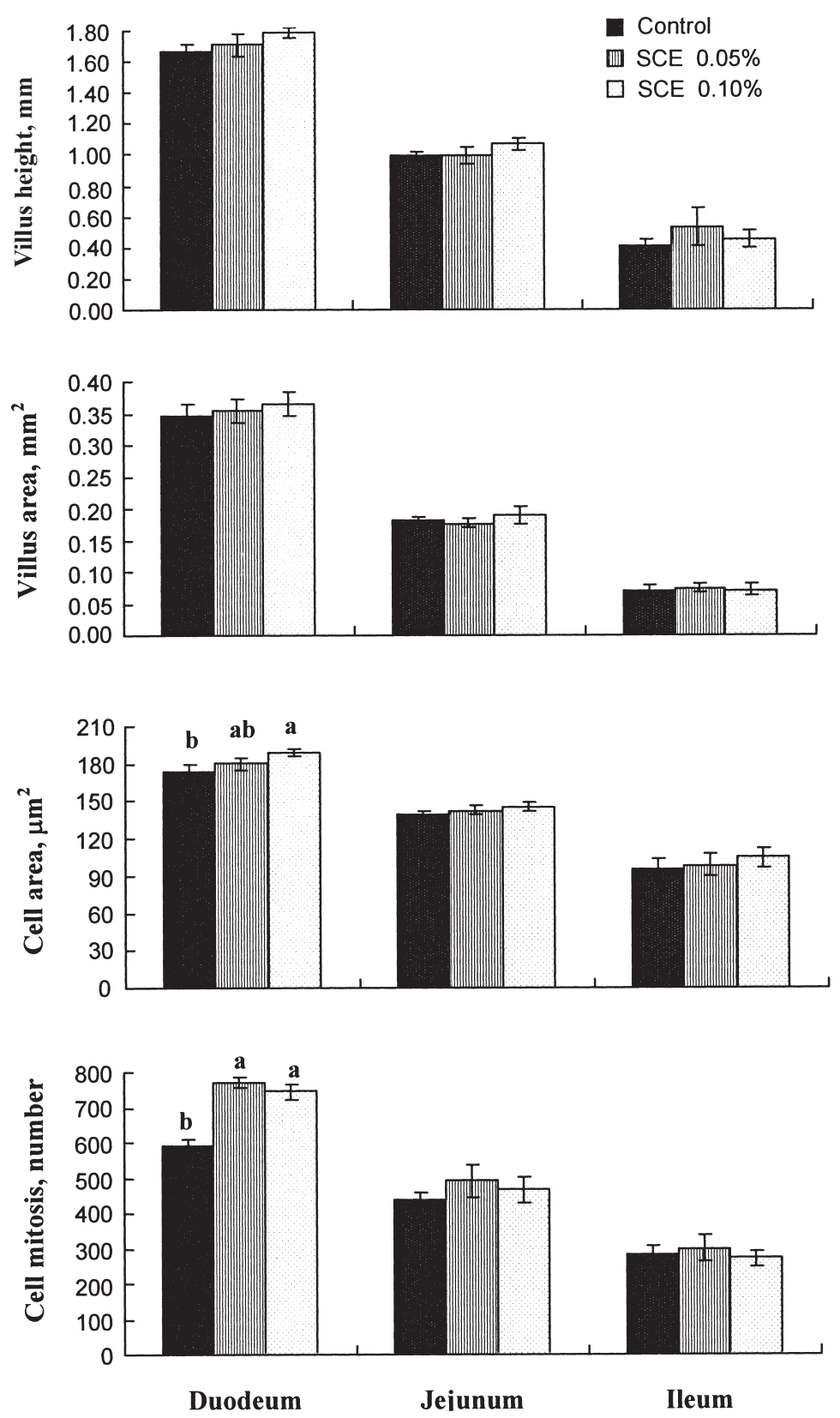

Figure 1. Villus height, villus area, cell area and cell mitosis of duodenal, jejunal and ileal parts in conventional layer chickens fed the control diet and the dietary 0.05 and $0.10 \%$ SCE diets ${ }^{\mathrm{a}, \mathrm{b}}$ indicate that means bearing different letter are different $(\mathrm{P}<0.05$; mean $\pm \mathrm{SE}, \mathrm{n}=4)$ 

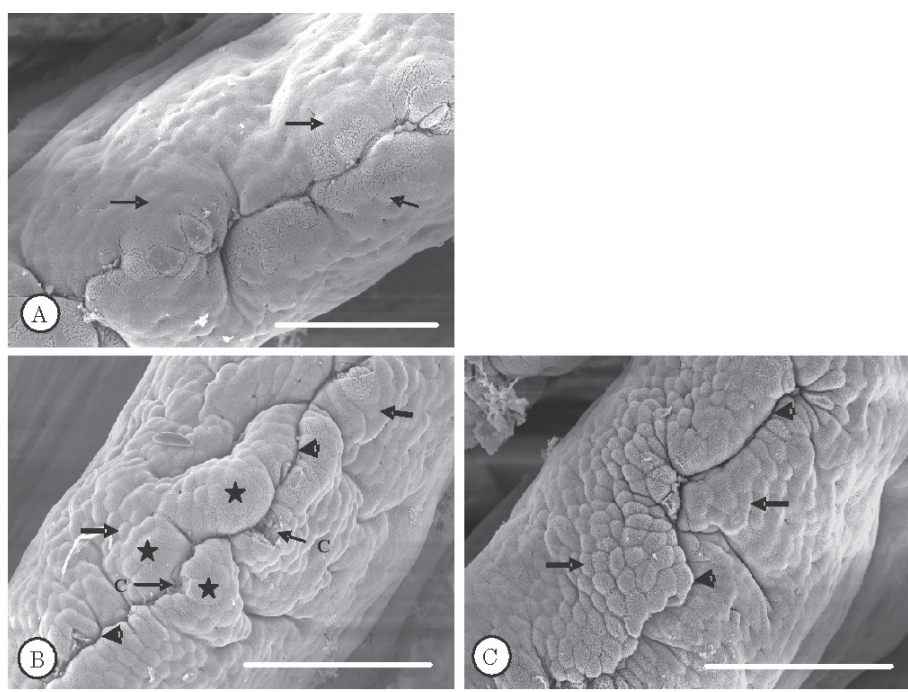

Figure 2. Duodenal villus apical surface in conventional layer chickens fed the dietary control (A; arrows, faintly protuberated cell), 0.05 (B; stars, cell clusters; large arrows, clearer cell protuberance; arrowheads, central sulcus; arrow with c, a few cell having no microvilli) and $0.10 \%$ SCE diets (C; arrows, clearer cell protuberance; arrowheads, central sulcus). Note the activated morphology change after feeding SCE diets. Scale bar $=50 \mu \mathrm{m}$
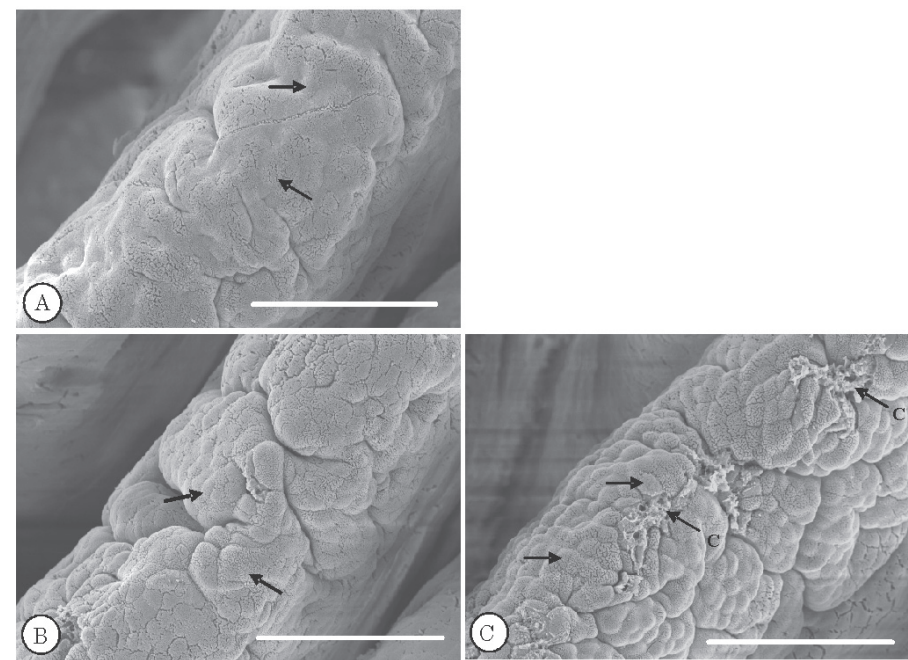

Figure 3. Epithelial cells on the jejunal villus apical surface in conventional layer chickens fed the dietary control (A; arrows, flat cell), 0.05 (B; arrows, faintly protuberated cell), and $0.10 \%$ SCE diets (C; arrows, protuberated cell; arrow with $\mathrm{C}$, some cells devoid of any microvilli). One can see the activated protuberated cells observed in the SCE group. Scale bar $=50 \mu \mathrm{m}$ 


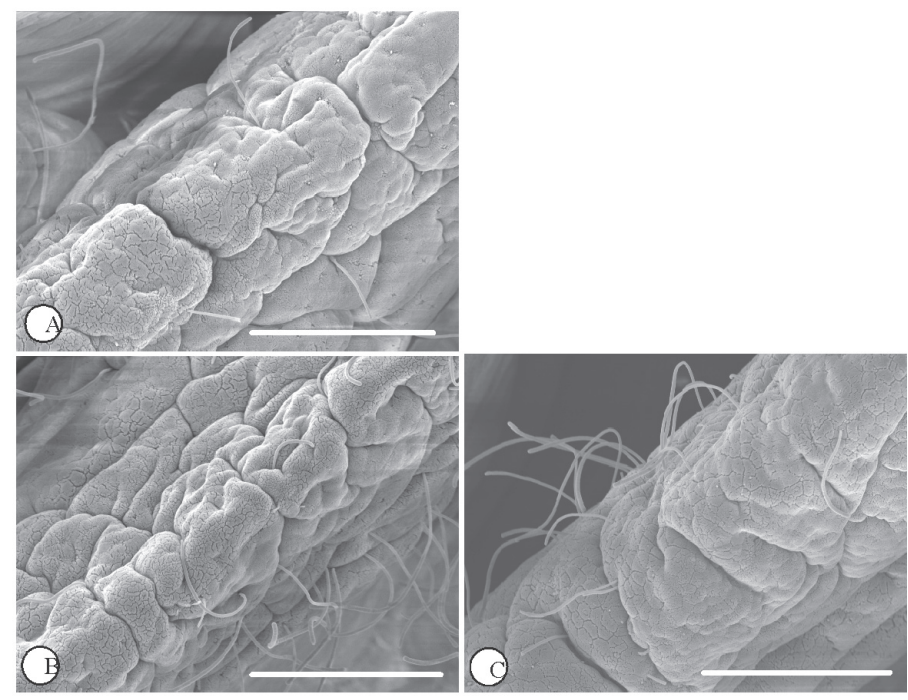

Figure 4. Epithelial cells on the ileal villus apical surface in conventional layer chickens fed the dietary control (A), 0.05 (B) and $0.10 \%$ (C) SCE diets. Segmented filamentous bacteria (SFB) appeared in all the SCE groups. Scale bar $=50 \mu \mathrm{m}$

\section{DISCUSSION}

In the previous feeding experiment using adult male Sanuki Cochin chickens (layer type), the birds fed dietary SCE tended to have better growth performance than the controls (Yamauchi et al., 2006). The main purpose of this study was to investigate whether the growth performance of young chickens, fed dietary SCE from 7 days of age to 10 weeks of age, can be much more improved by hastening the start time of feeding, and to investigate how alterations in intestinal histology could be observed in these chickens. In this study, we failed to obtain a significant increase in growth performance in the SCE-fed chickens, even with a long feeding period of 9 weeks. One-week-old male broiler chickens administered with SCE into the crop for 3 consecutive days showed a significant weight gain and improved feed efficiency at 7 weeks day-old (El-Abasy et al., 2002). As it is well known that a layer-type chicken does not become so big, this result is probably due to the use of layer-type chickens. However, the body weight gains of 0.05 and $0.10 \%$ SCE groups were 6.2 and $5.7 \%$ heavier, respectively, than the control group. Since the small intestine is the site for nutritional absorption from the intestinal lumen through the mucosal epithelial cells into the blood or the lymphatic system (Caspary, 1992), and as the nutritional composition of the diets in each group was almost identical, the present trend of improvement in weight gain of the SCE group might be responded by the structural hypertrophy of the 
intestinal villi and epithelial cells due to dietary SCE in this group than in the control, as will be described later.

Villus height, villus size, cell area and cell mitosis number, as well as epithelial cells on the villus tip, are thought to be easily altered by ingested dietary factors and to be the most suitable parameters by which to histological assess the enteral nutrient absorption of feed ingredients. In the present results, intestinal villus height, villus area, cell area and cell mitosis number of the duodenum showed a tendency to be of higher values in all the SCE groups, and the duodenal cell area and cell mitosis values were significantly increased in the $0.10 \%$ SCE groups. Long villi mean an increased surface area capable of greater absorption of available nutrients (Caspary, 1992), in which greater villus height and numerous cell mitoses are indicators of activated villus function (Langhout et al., 1999). Actually, such long villi were reported in piglets that showed an increased body weight gain (Zijlstra et al., 1996), in turkeys fed dietary amylase (Ritz et al., 1995) and in chickens showing a high activity of amylase in the intestinal content (Samanya and Yamauchi, 2002). Adversely, the short villi correspond with reductions of enzyme activities such as the mucosal lactase and sucrase (Park et al., 1998), and the total lactase phlorizin hydrolase and mucosal protein concentration (Dudley et al., 1998). The short villi were accompanied by reductions in the villus surface area (Park et al., 1998), resulting in the reduced absorptive functions. These reports suggest that the present long villi might be histologically hypertrophied, and the short villi might be hypotrophied. Furthermore, increased villus size induces cell proliferation in the crypt (Lauronen et al., 2000). It has been suggest that feed nutrients are strongly related to gut structure and that villus height could predict weight gain (Pluske et al., 1996). Increased body weight was associated with an increase in villus height and size in piglets (Zijlstra et al., 1996), in villus height, cell area and cell mitosis in chickens (Maneewan and Yamauchi, 2004), and in villus height in turkeys (Ritz et al., 1995). From these related papers, the present SEM might slightly histologically hypertrophy the intestinal villi, resulting 5 6\% heavier body weight gain in the 0.05 and $0.10 \%$ SCE groups than the control.

Epithelial cells on the villus apical surface were altered by feed withdrawal and re-feeding, and affected by dietary feed components. The flat epithelial cells on the duodenal and jejunal villus apical surfaces in the control developed into protuberated cells in the SCE groups. In addition, many cell clusters aggregated by many protuberated cells and a few cells with no microvilli were found around the extrusion zone on the duodenal villus tip of the $0.05 \%$ SCE group. Skrzypek et al. (2005) reported that the size and activity of extrusion zone is a good marker of epithelial cell turnover, corresponding to our results that cell mitosis numbers increased in the $0.05 \%$ SCE group. Actually, protuberated cells on the villus tip were observed in chickens that showed rapid growth performance (Maneewan and Yamauchi, 2004). Pluske et al. (1996) have also described a strong relationship 
between feed nutrients and gut structure. These related papers suggest that dietary SCE might induce the present protuberated cells.

Compared with the previous hypertrophied epithelial cells and the lack of SFB in the ileum in the previous birds fed SCE as adults (Yamauchi et al., 2006), the present duodenal and jejunal epithelial cells were histologically hypertrophied by feeding SCE from 2 to 7 weeks. In addition, as characteristic morphological features, SFB were observed in the SCE groups. The intestinal mucosa is the first barrier encountered by microorganisms, because it is exposed to high amounts of dietary antigens. These SFB are the most potent indigenous bacteria that stimulate the intestinal immune system; it was also reported that SFB were phagocytised into the ileal epithelial cells, and this phagocytosis could be the first triggering step for an immunological response to SFB (Yamauchi and Snel, 2000). SCE also induces immuno-stimulation (El-Abasy et al., 2002) and immuno-protective (ElAbasy et al., 2003) effects in chickens. Therefore, the appearance of SFB might be related to feedings of SCE from an early stage of growth. These effective functions of SCE might improve the circumstance of the intestinal lumen, resulting in more hypertrophied epithelial cells in the present young birds than those of the previous adult chickens. This agrees with the fact that a healthy intestinal lumen improved villus height, resulting in better growth performance (Santin et al., 2001). The reason why the present hypertrophied intestine did not induce significant body weight gain may be related to the use of layer-type chickens, as one-week-old male broiler chickens administered SCE into the crop for 3 consecutive days showed a greater weight gain and improved feed efficiency at the age of 7-weeks (El-Abasy et al., 2002).

\section{CONCLUSIONS}

The long-term feeding of dietary sugar cane extract (SCE) to layer chickens from 2 to 10 weeks of age appears to induce the structurally hypertrophied intestinal villi and epithelial cells, resulting in the $5 \sim 6 \%$ heavier body weight gain in the 0.05 and $0.10 \%$ SCE groups than the control.

\section{REFFERENCES}

Amer S., Na K.-J., El-Abasy M., Motobu M., Koyama Y., Koge K., Hirota Y., 2004. Immunostimulating effects of sugar cane extract on X-ray radiation induced immunosuppression in the chicken. Int. Immunopharmacol. 4, 71-77

Burgat V., 1991. Residues of drugs of veterinary use in food. Rev. Prat. 41, 985-990

Bywater R.J., 2005. Identification and surveillance of antimicrobial resistance dissemination in animal production. Poultry Sci. 84, 644-648 
Caspary W.F., 1992. Physiology and pathophysiology of intestinal absorption. Amer. J. Clin. Nutr. $55,299 \mathrm{~S}-308 \mathrm{~S}$

Dudley M.A., Wykes L.J., Dudley Jr. A.W., Burrin D.G., Nichols B.L., Rosenberger J., Jahoor F., Heird W.C., Reeds P.J., 1998. Parenteral nutrition selectively decreases protein synthesis in the small intestine. Amer. J. Physiol. Gastrointest. L. 274, G131-G137

El-Abasy M., Motobu M., Na K.-J., Shimura K., Nakamura K., Koge K., Onodera T., Hirota Y., 2003. Protective effects of sugar cane extracts (SCE) on Eimeria tenella infection in chickens. J. Vet. Med. Sci. 65, 865-871

El-Abasy M., Motobu M., Nakamura K., Koge K., Onodera T., Vainio O., Toivanen P., Hirota Y., 2004. Preventive and therapeutic effects of sugar cane extract on cyclophosphamide-induced immunosuppression in chickens. Int. Immunopharmacol. 4, 983-990

El-Abasy M., Motobu M., Shimura K., Na K.-J., Kang C.-B., Koge K., Onodera T., Hirota Y., 2002. Immunostimulating and growth-promoting effects of sugar cane extract (SCE) in chickens. J. Vet. Med. Sci. 64, 1061-1063

Iji P.A, Saki A., Tivey D.R., 2001. Body and intestinal growth of broiler chicks on a commercial starter diet: 1. Intestinal weight and mucosal development. Brit. Poultry Sci. 42, 505-513

Imondi A.R., Bird F.H., 1966. The turnover of intestinal epithelium in the chick. Poultry Sci. 45, $142-147$

Lauronen J., Pakarinen M.P., Kuusanmaki P., Savilahti E., Vento P., Paavonen T., Halttunen J., 2000. Intestinal adaptation after massive proximal small bowel resection in the pig. Brit. Poultry Sci. 41, 416-423

Lo D.Y., Chen T.H., Chien M.S., Koge K., Hosono A., Kaminogawa S., Lee W.C., 2005. Effect of sugar can extract on the modulation of immunity in pigs. J. Vet. Med. Sci. 67, 591-597

Longhout D.J., Schutte J.B., Van L.P., Wiebenga J., Tamminga S., 1999. Effect of dietary high and low methyllated citrus pectin on the activity of the ileal microflora and morphology of the small intestinal wall of broiler chick. Brit. Poultry Sci. 40, 340-347

Maneewan B., Yamauchi K., 2004. Intestinal villus recovery in chickens refed semi-purified protein-, fat-, or fibrefree pellet diets. Brit. Poultry Sci. 45, 163-170

Motobu M., Amer S., Koyama Y., Hikosaka K., Sameshima T., Yamada M., Nakamura K., Koge K., Kang C.B., Hayasidani H., Hirota Y., 2006. Protective effects of sugar cane extract on endotoxic shock in mice. Phototherapy Res. 20, 359-363

Park Y.K., Monaco M.M., Donavan S.M., 1998. Delivery of total parenteral nutrition (TNP) via umbilical catheterization: development of a piglet model to investigate therapies to improve gastrointestinal structure and enzyme activity during TPN. Biol. Neonate 73, 295-305

Pluske J.R., Thompson M.J., Atwood C.S., Bird P.H., Williams I.H., Hartmann P.E., 1996. Maintenance of villus height and crypt depth, and enhancement of disaccharide digestion and monosaccharide absorption, in piglets fed on cows' whole milk after weaning. Brit. J. Nutr. 76, 409-422

Ritz C.W., Hulet R.M., Self B.B., Tsao T., 1995. Growth and intestinal morphology of male turkeys as influenced by dietary supplementation of amylase and xylanase. Poultry Sci. 74, 1329-1334

Samanya M., Yamauchi K., 2002. Histological alterations of intestinal villi in chickens fed dried Bacillus subtilis var. natto. Comp. Biochem. Physiol. Pt A, 133, 95-104

Santin E., Maiorka A., Macari M., 2001. Performance and intestinal mucosa development of broiler chickens fed diets containing Saccharomyces cervisiae cell wall. J. Appl. Poultry Sci. 10, 236-244

SAS, 1997. SAS ${ }^{\circledR}$ User's Gide: Statistics. Version 6.12 Edition. SAS Institute Inc. Cary, NC

Skrzypek T., Valverde Piedra J.L., Skrzypek H., Wolinski J., Kazimierczak W., Szymanczyk S., Pawlowska M., Zabielski R., 2005. Light and scanning electron microscope evaluation of the postnatal small intestinal mucosa development in pigs. J. Physiol. Phamacol. 56, 71-87 
Sorum H., Sunde M., 2001. Resistance to antibiotics in the normal flora of animals. Vet. Res. 32, 227-241

Steel R.G.D., Torrie J.H., 1980. Principles and Procedures of Statistics: A Biometrical Approach. 2nd Edition. McGraw-Hill Inc., New York

Tarachi P., Yamauchi K., 2000. Effects of luminal nutrient absorption, intraluminal physical stimulation, and intravenous parenteral alimentation on the recovery responses of duodenal villus morphology following feed withdrawal in chickens. Poultry Sci. 79, 1579-1585

Yamauchi K., Buwjoom T., Koge K., Ebashi T., 2006. Histological alterations of the intestinal villi and epithelial cells in chickens fed dietary sugar cane extract. Brit. Poultry Sci. 47, 544-553

Yamauchi K., Snel J., 2000. Transmission electron microscopic demonstration of phagocytosis and intracellular processing of segmented filamentous bacteria by intestinal epithelial cells of the chick ileum. Infec. Immunity 68, 6496-6504

Zijlstra R.T., Whang K.Y., Easter R.A., Odle J., 1996. Effect of feeding a milk replacer to earlyweaned pigs on growth, body composition, and small intestinal morphology, compared with suckled littermates. J. Anim. Sci. 74, 2948-2959 